\title{
The Effect of Multi-Dimensional Performance Measurement System on Market Orientation
}

\author{
Rapiah Mohamed
}

\begin{abstract}
The objective of this study is to examine the effect of performance measurement system design on market orientation behavior. The data were collected using mail survey to top management of Malaysian listed companies. The results show that non-financial measures have a positive and significant relationship with market orientation. An implication of these findings is that the managers should include both financial and non-financial measures in designing their PMS. Theoretically, this study contributes to the resource-based theory by identifying PMS as an antecedent to build market orientation and thus contribute to develop an organizational competitive advantage.
\end{abstract}

Index Terms-Multi-dimensional performance measures, market orientation.

\section{INTRODUCTION}

The Resource-Based View (RBV) theory argues that organisations can develop sustained competitive advantage by creating value for both the customers and the organisation, and developing organisational capabilities that are rare and difficult for competitors to imitate [1], [2]. According to RBV theory, market orientation is one of the organisational capabilities [3]-[5]. Market orientation is important since it can contribute to organisational continuous learning and knowledge accumulation through continuously collecting information about customers and competitors and using the information to create superior customer value and competitive advantage [6].According to [7], three sets of antecedents for market orientation, which are, top management, interdepartmental factors and organisational systems. Performance evaluation and rewards are important factor to develop a market-driven business [7]. They argue that if managers are primarily evaluated on the basis of short-term profitability and sales they are likely to focus on these criteria and neglect market factors such as customer satisfaction that assure the long-term health of an organisation. Their findings suggest that market-based reward systems and decentralised decision making has a strong effect on facilitating market orientation.

The link between market orientation and business performance has received substantial attention in the literature, however, there has been less attention given to the process for creating and developing a market orientation behavior within organizational. Previous studies asserted that a multi-dimensional performance measurement system (PMS) has an ability to enhance organisational capabilities

Manuscript received October 10, 2013; revised December 9, 2013.

Rapiah Mohamed is with the College of Business, School of Accountancy, Universiti Utara Malaysia, 06010 Sintok, Kedah, Malaysia (e-mail: rapiah@uum.edu.my). i.e. market orientation [8], [9]. Although, the RBV theory does not recognise strategic performance measurement system (SPMS) as a source for competitive advantage, a few studies agree that multi-dimensional PMS is an important antecedent to develop market orientation [3], [7], [10]. Unfortunately, not much empirical research has been conducted to investigate the relationship of PMS and market orientation. Therefore this study focuses on the multi-dimensional performance measures as an antecedent to create market orientation behavior as suggested by [7]. The rest of this paper is divided into five sections. Section two is the literature review, section three details the methodology, followed by the results and discussion in section four and finally the last section provides the conclusion.

\section{LITERATURE REVIEW}

\section{A. Multi-Dimensional Performance Measurement System}

A performance measurement system (PMS) is defined by [11] as a set of formal, information-based routines and procedures that managers use to maintain or alter patterns in organisational activities. Traditionally, PMS is focus on financial measures. However, numerous authors highlighted that the traditional PMS has many limitations (see for example, [9], [12], [13]). Traditional financial measures do not match entirely with the competencies and skills that companies require to face today's business environment [12]. Traditional financial measures have a backward-looking focus and lack of explicative and predictive power. Besides, traditional measures have a tendency to focus on the individual or the function, not the process that is at the core of management. Moreover, traditional financial measures encourage short-term vision due to the lack of strategic focus [12].

Due to the limitations of traditional PMS, many researchers such as [9], [11] suggest that an effective PMS must include both financial and non-financial measures in order to stay relevant with the changes in current's business environment. Advocates of the multi-dimensional approach argue that a broad set of measures keeps managers from sub-optimising by ignoring relevant performance dimensions or improving one measure at the expense of others. Further, the use of a broad set of measures can also help organisations achieve higher performance (see for example [8], [9], and allows managers to better monitor employees' action and guide firm behaviour, and it provides better information on changes in economy and competition [14].

\section{B. Market Orientation}

Market orientation is defined by [15] as organisational-wide information gathering and 
dissemination, and a quick response to current and future customer needs and preferences. They described that market orientation as a set of activities in organisation. While [16] categorise market orientation into three dimensions: customer orientation - the firm's understanding of the target market; competitor orientation - the firm's understanding of the long-run capabilities of present and prospective competitors; and inter-functional coordination - the coordinated utilisation of company resources to create superior customer value. They conceptualised market orientation from organisational cultural perspective. This study uses the definition provided by [16].

Three sets of antecedents for market orientation are - top management, interdepartmental factors and organisational systems [7]. Top level management includes the emphasis of the managers towards market orientation and the level of risk aversion concerned with new product development. Inter-departmental factors represent the structure of existing relations between the functional areas and levels of an organisation (this is represented through conflict and cohesion of the heart of the organisation). Organisational systems reflect the influence of formalization, centralization, departmentalization and reward systems.

\section{Multi-Dimensional Performance Measurement System and Market Orientation}

In order to develop a market oriented culture an organization need to have a specific structure and system to encourage employees to adopt market orientation attitude [7]. A performance measurement system is one mechanism that can be used for creating and sustaining market oriented behaviors throughout the organization [10]. They explain that a performance management system is an initiative proposed by top management that sets up a process for the on-going evaluation of worker productivity along with continuous feedback, with the ultimate goal being continual development of employee skills and activities that enhance the effectiveness of the organisation. They are also argued that through performance measurement system like Balanced Scorecard, an organisation can monitor and improve the financial and non-financial performance. Hence, it can help for organisation to cultivate positive behaviour to be market oriented organisation.

Based on the previous literature, this study proposes that multi-dimensional PMS is positively related to market orientation.

\section{METhOdOLOGY}

Data were collected through a structured questionnaire that was sent to top management of Malaysian Listed Companies. Out of 778 questionnaires sent, 145 are usable, yielded a response rate of $18.6 \%$. The sample was divided into two groups according to early and late response to check for non-response bias test. From the test, it shows that no significant differences between the two groups, indicate that non-response bias is not an issue in this study. Cronbach's alpha is used to check the questionnaire stability for all of its components. All the items have a Cronbach's alpha of above 0.70 , which exceeds the acceptable standard of reliability analysis of 0.70 [17], meaning that the constructs have good internal consistency.

For market orientation, the instrument developed by [16] was adopted. The instrument consisted of three subscales used to measure customer orientation, competitor orientation and interfunctional coordination. Multi-dimensional PMS is measure using instrument developed by [8], [9], [18]. There are six dimensions, covering 30 items in this section, but in the factor analysis, 4 items are excluded giving a total of 26 items to be analysed. The six dimensions are financial, quality, flexibility, resource utilisation, customer satisfaction, and innovation and learning.

\section{FINDINGS AND DISCUSSION}

Table I shows the result of regression analysis for overall multi-dimensional that consists of financial and non-financial. The result indicates that multi-dimensional PMS are positively and significantly related to market orientation. The result shows that 29.2 percent $\left(\operatorname{adj} . R^{2}=.292\right)$ of the market orientation are explained by the independent variables. The $\mathrm{R}^{2}$ was statistically significant with $F=60.293$ and $p<.001$.

TABLE I: RESULTS OF REGRESSION OF OVERALL PMS: DV-MARKET ORIENTATION

\begin{tabular}{lcccc}
\hline \multicolumn{4}{c}{ Regression Coefficients } \\
Variable & \multicolumn{5}{c}{ B } & Std. Error & Beta \\
\hline Multi-dimensional & & .433 & .056 & $.545^{* * *}$ \\
PMS & .297 & & \\
$R^{2}$ & .292 & & \\
Adj. $R^{2}$ & $7.765^{* * *}$ & & \\
$t$ & $60.293^{* * *}$ \\
$F$ & &
\end{tabular}

The result also indicates that non-financial measures are positively and significantly related to market orientation. The result shows that 33.5 percent $\left(R^{2}=.335\right)$ of the market orientation are explained by the independent variables. The R2 was statistically significant with $F=37.307$ and $p<.0019$ (See Table II).

\begin{tabular}{|c|c|c|c|c|}
\hline \multirow[b]{2}{*}{ Variables } & & \multicolumn{3}{|c|}{ Regression Coefficients } \\
\hline & & $B$ & Std. Error & Beta \\
\hline Financial & & .014 & .068 & .017 \\
\hline Nonfinancial & & .354 & .051 & $.577 * * *$ \\
\hline$R^{2}$ & .344 & & & \\
\hline Adj. $R^{2}$ & .335 & & & \\
\hline$t$ & $16.684 * * *$ & & & \\
\hline$F$ & $37.307 * * *$ & & & \\
\hline
\end{tabular}

Table III provides the result of the regression of each dimension of non-financial measures with market orientation. From 5 dimensions of non-financial, only customer satisfaction has a significant influence on market orientation. From the result, we can see that flexibility and innovation and learning have a negative impact on market orientation.

The findings are consistent with the view that 
multi-dimensional PMS, which includes non-financial indicators such as quality, customer satisfaction and innovation and learning, can provide a strategic feedback system (See [8], [9]). Non-financial can affect learning from experience because of the feedback that it provides to the managers, where feedback can give information about errors and guidance to managers for continuous improvement [19]. The non-financial measures reflect the measurement of an organisation's capabilities by measuring resource utilisation, flexibility, quality, customer and innovation and learning. This information then allows senior management to take action that will enhance market oriented behaviour.

\begin{tabular}{|c|c|c|c|c|}
\hline \multirow{2}{*}{ Variables } & & \multicolumn{3}{|c|}{ Regression Coefficients } \\
\hline & & $B$ & Std. Error & Beta \\
\hline Quality & & .077 & .051 & .134 \\
\hline Flexibility & & -.008 & .060 & -.016 \\
\hline $\begin{array}{l}\text { Resource } \\
\text { utilisation }\end{array}$ & & .033 & .040 & .077 \\
\hline $\begin{array}{l}\text { Customer } \\
\text { satisfaction }\end{array}$ & & .332 & .080 & $.536 * * *$ \\
\hline $\begin{array}{l}\text { Innovation } \\
\& \text { learning }\end{array}$ & & -.023 & .057 & -.047 \\
\hline$R^{2}$ & .395 & & & \\
\hline Adj. $R^{2}$ & .369 & & & \\
\hline$t$ & $14.799 * * *$ & & & \\
\hline$F$ & $15.006^{* * * *}$ & & & \\
\hline
\end{tabular}

The results are also in line with [10]. According to [10], PMS provides information on financial and non-financial measures that can help employees to have clear targets and goals that are always in line with the organisation's objectives and mission. Setting performance targets for employees clearly communicates the attitudes and expectations of top management. This in turn will lead to a behaviour change in employees that will bring their behaviour in line with the goals of top management. Therefore, multi-dimensional PMS can help to develop and sustain market oriented behaviour throughout the organisation. The result shows that customer satisfaction has a significant effect on market orientation. This finding corroborates the ideas of [7], who suggested that employees in organization that emphasize customer satisfaction and market orientation behavior will more readily generate market intelligence, disseminate it internally and be responsive to market needs.

The findings provide support for various claims in the literature that organisations need to consider both financial and non-financial measures (see for example [12], [13], [20]). [20], for example, mentioned that traditional performance measurement systems might encourage conservatism and promote comfort and clarity. In other words traditional financial measures may discourage senior managers from innovating as well as from searching for new ways and developing sources of competitive advantage. Further, [20] suggested that performance measurement systems should consider including both measures - financial and non-financial. By providing and measuring information for both measures, it can help senior managers focus organisational attention, resources and efforts towards critical success factors and thus can help to develop organisational competitive advantage.

\section{CONCLUSION}

The main purpose of this paper is to examine the relationship between multi-dimensional PMS and market orientation. The link between market orientation and organizational performance has been discussed well in the literature. However, to date, little has been offered on the antecedents of market orientation, particularly, that relates to PMS [10], [21] mention that the extant literature needs a better understanding of how the impact of the antecedents of market orientation varies across different business and cultural contexts.

The findings from this study provide empirical evidence that a multi-dimensional PMS is important to assist managers to develop a market oriented behavior. The result show that the adoption of financial measure alone is not sufficient, and organization should also include non-financial measures such as quality, flexibility, resource utilization, customer satisfaction, and innovation and learning as their performance measures. The adoption of multi-dimensional performance measures can influence managerial actions to focus attention and effort on factors critical to the success of the organization.

The evidence from this study suggests that in order for manager to create market orientation behavior, it is important for managers to review their PMS and adopt a multi-dimensional PMS. A PMS can play a pivotal role in influencing organizational behavior, as the PMS is designed by top management that sets up a process for employees' on-going evaluation and continuous improvement with the ultimate goals are to improve an organizational efficiency and effectiveness. Thus, in designing PMS, managers should develop their strategic and operational goals with a market orientation being a key component. Future research might be focus in this issue by looking in-depth into the process of developing market orientation behavior. Future researcher can propose an integrated framework to help organization to establish market orientation.

\section{REFERENCES}

[1] R. M. Grant, "The resource-based theory of competitive advantage: Implications for strategy formulation," California Management Review, pp. 114-135, Spring 1991.

[2] J. Barney, "Firm resources and sustained competitive advantage," Journal of Management, vol. 17, no. 1, pp. 99-120, 1991.

[3] G. S. Day, "The capabilities of market-driven organizations," Journal of Marketing, vol. 58, no. 4, pp. 37-52, 1994.

[4] J. F. Henri, "Management control systems and strategy: A resource-based perspective," Accounting, Organization \& Society, vol. 31, no. 6, pp. 529-558, 2006.

[5] G. T. M. Hult and D. J. Ketchen, "Does market orientation matter? A test of the relationship between positional advantage and performance," Strategic Management Journal, vol. 22, pp. 899-906, 2001.

[6] L. Y. M. Sin, A. C. B. Tse, V. C. S. Heung, and F. H. K. Yim, “An analysis of the relationship between market orientation and business performance in the hotel industry," Hospitality Management, vol. 24, pp. 555-577, 2005

[7] B. J. Jaworski and A.K. Kohli "Market orientation: Antecedents and consequences," Journal of Marketing, vol. 57, no. 3, pp. 53-70, 1993.

[8] L. Fitzgerald, R. Johnston, T. J. Brignall, R. Silvestro, and C. Voss, Performance Measurement in Service Businesses, London: CIMA, 1991.

[9] R. Kaplan and D. P. Norton, "The balanced scorecard - measures that drive performance," Harvard Business Review, pp. 71-79, January/February 1992.

[10] B. A. Martin and J. H. Martin, "Building a market-oriented organisational environment: An implementation framework for small organisations," Mid-American Journal of Business, vol. 20, no. 2, pp. 45-58, 2005. 
[11] R. Simons, Performance Measurement \& Control Systems for Implementing Strategy, USA: Prentice Hall, 2000.

[12] G. K. Kanji, "Performance measurement system," Total Quality Management, vol. 13, no. 5, pp. 715-728, 2002.

[13] CIMA. (2004). Latest trends in corporate performance measurement. Technical Briefing: Developing and Promoting Strategy. [Online]. Available: www.cimaglobal.com

[14] L. Bryant, D. A. Jones, and S. K. Widener, "Managing value creation within the firm: An examination of multiple performance measures," Journal of Management Accounting Research, vol. 16, pp. 107-131, 2004.

[15] A. K. Kohli and B. J. Jaworski, "Market orientation: The construct, research propositions, and managerial implications," Journal of Marketing, 1990, vol. 54, no. 2, pp. 1-18.

[16] J. C. Narver and S. F. Slater, "The effect of a market orientation on business profitability," Journal of Marketing, 1990, vol. 54, no. 4, pp. 20-35.

[17] J. Pallant, SPSS Survival Manual, Australia: Allen \& Unwin, 2001.

[18] Z. Hoque, L. Mia, and M. Alam, "Market competition, computer-aided manufacturing and use of multiple performance measures: An empirical study," British Accounting Review, vol. 33, pp. 23-45, 2001.
[19] L. K. Ong, "Does adding nonfinancial value drivers to a summary financial measure improve the learning and performance of managers?' Unpublished Ph.D. Thesis, University of Southern California, 2003.

[20] J. F. Henri, "Three essays on performance measurement system," Unpublished Ph.D. Thesis, Universite de Montreal, 2003.

[21] A. H. Kirca, S. Jayachandran, and W. O. Bearden, "Market orientation: A meta-analytic review and assessment of its antecedent," Journal of Marketing, pp. 24-41, April 2005.

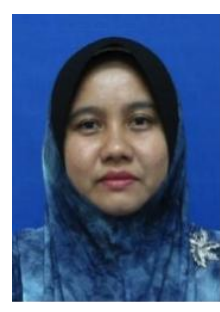

Rapiah Mohamed is a senior lecturer of accounting at the School of Accountancy at the Universiti Utara Malaysia. Her undergraduate degree in accounting is from Universiti Utara Malaysia, her MBA in Accounting is from Monash University, and her Ph.D. is from the Universiti Teknologi MARA (UiTM). Her research areas are performance measurement system, management control system and corporate social responsibility. She has published several articles in the local and international refereed journals. She is also a presenter at various local and international conferences. Her current research projects are corporate sustainability and performance measurement of SMEs. 